HERTA GESSNER

Veränderliche Sterne am Südhimmel

Teil IV

Veroffentlichungen der Sternwarte in Sonneberg Band 6, Heft 6 

AKADEMIE DER WISSENSCHAFTEN DER DDR Zentralinstitut für Astrophysik

\title{
Sternwarte Sonneberg
}

\author{
Veröffentlichungen \\ Band VI
}

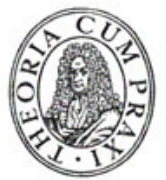

Akademie-Verlag · Berlin 1963-1974 
